
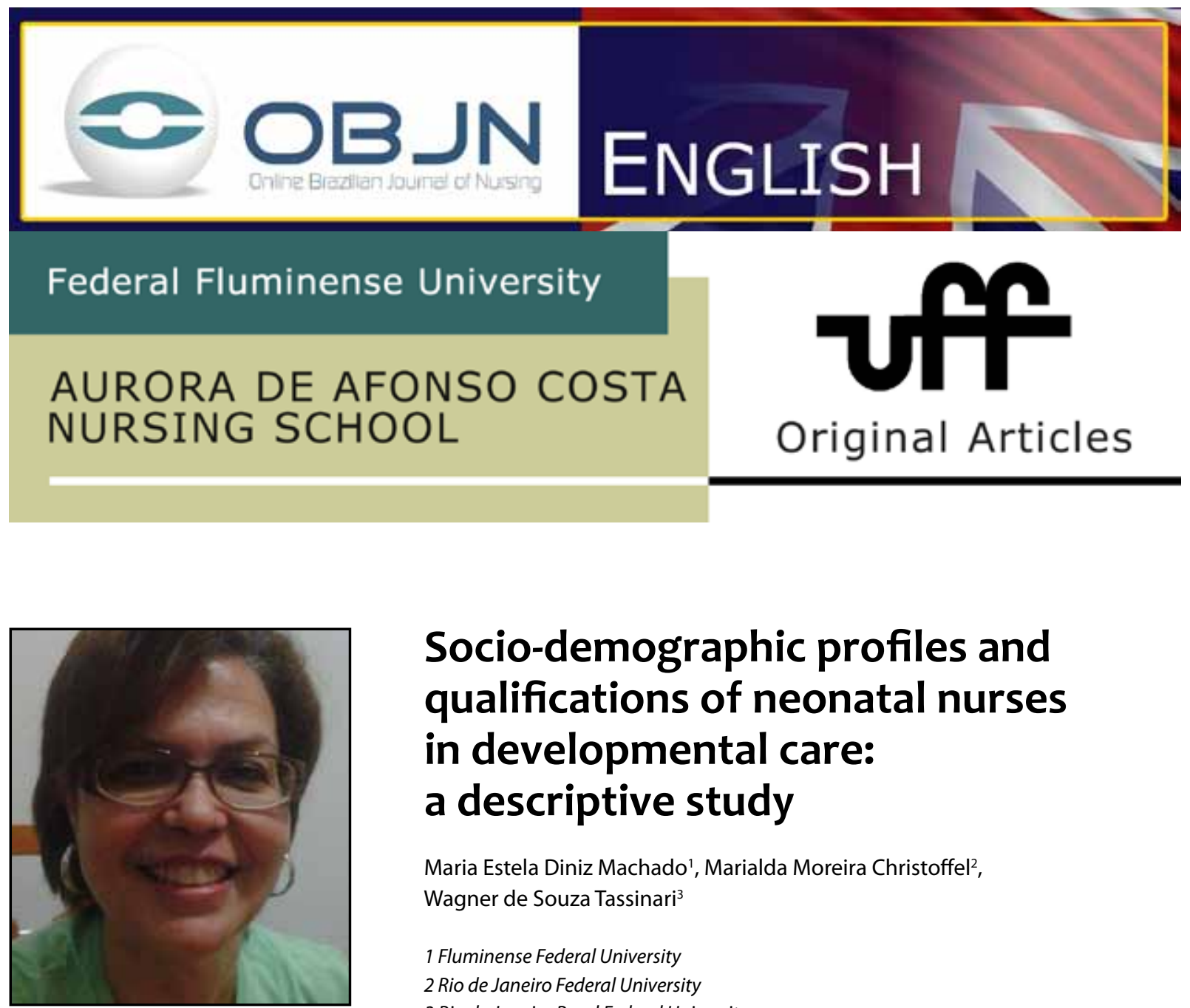

\title{
Socio-demographic profiles and qualifications of neonatal nurses in developmental care: a descriptive study
}

Maria Estela Diniz Machado', Marialda Moreira Christoffel ${ }^{2}$, Wagner de Souza Tassinari³

1 Fluminense Federal University

2 Rio de Janeiro Federal University

3 Rio de Janeiro Rural Federal University

\begin{abstract}
Aim: To describe the socio-demographic profile and to analyze the qualifications of nurses involved in the developmental care of the newborn in a neonatal unit. Method: This is a census and descriptive study performed in 10 neonatal care units, part of the public health system of the municipality of Rio de Janeiro, Brazil. The sample was composed of 111 nurses who work with newborns. Results: $91 \%$ are female; the majority (44.1\%) are between $30-49$ years of age; they work in more than one location ( $86.4 \%) ; 45 \%$ finished their studies less than 10 years ago; $42.3 \%$ have less than 10 years of professional experience; $73.8 \%$ are specialists; $72 \%$ are satisfied with their work routine; $78,3 \%$ get some information regarding the developmental care of the newborn, the majority of these (37.9\%) during their undergraduate and specialization courses; $63 \%$ have not been taken part in workshops/training about developmental care, and $44.1 \%$ are unaware that their working places have any sort of directives, protocols or routines about developmental care. Conclusion: It is recommended that permanent updates, workshops, and training sessions for nurses regarding developmental care be introduced.
\end{abstract}

Descriptors: Premature; Neonatal Intensive Care Units; Neonatal Nursery. 


\section{INTRODUCTION}

Neonatal Intensive Care Units (NICU) are considered a critical area, whose purpose is to support acute or potentially acute cases in newborns (NB) by provding specialized professional care ${ }^{(1)}$. Technological development in NICU has led to a reduction in neonatal mortality rates, including among low-weight and premature NB, conditions which were previously considered incompatible with life ${ }^{(2)}$.

The NICU environment provides the newborn with an atmosphere that is different from the intrauterine environment, ideal for the NB's growth and development. Such an environment can generate positive or negative sensorial experiences for the newborn. Some studies have demonstrated that elevated noise and luminosity levels, and constant harmful interventions (excessive handling, painful and repetitive proceedings that result in physiological and behavioral disorganization) can lead to deleterious effects on the immature brain, and can alter the subsequent construction of the development line, causing cognitive, visual and motor deficiencies, among others ${ }^{(3)}$.

To minimize or prevent such conditions implies the need to introduce developmental care supported by public health policies involving increases humanization. A particular example is the Brazilian National Low-Weight NB Care Policy - the Kangaroo Method (MC, in Portuguese), that is concerned with the individual care of the NB. This involves support to the family, reduction in noise and luminosity in the environment, the preservation of sleep and rest, the control and management of pain, and the avoiding of excessive handling resulting from a more careful observation based on approaching tips provided by the NB himself(4).

Based on the complexity and specificity of developmental care, and the necessary competence of the nurse as a team leader and as a care manager when it comes to providing support to the $\mathrm{NB}^{(2 ; 5)}$, this study aims to describe the socio-demographic profile of such professionals, and to analyze the qualifications of these individuals providing care to newborns in neonatal units.

\section{METHOD}

This is a census, descriptive study, performed with 10 nurses in neonatal units of the public health network system of the municipality of Rio de Janeiro, who take care of the NB. The criteria for exclusion were those professionals who were away on vacation, medical leave, and/or premium leave ${ }^{1}$ during the period of data collection. The nurses were recruited on the basis of their monthly work schedule in each unit, and were invited to participate in the research after the explanation of the goals of the study. A numbered questionnaire was handed to the participant and returned to the researcher after completion and, in the absence of the investigator, placed in a sealed envelope in a box located in the unit. Those who worked simultaneously in more than one researched unit were excluded from one of them. From the total of 202 eligible professionals, 111 participated in this study (Image 1).

1Translator's Note: This is a type of "leave" that workers acquire after many years of service, usually between 5 to 10 years of public service. It is given an extra paid vacation time, together with the regular 30-day vacation leave. 
Image 1 - Flowchart demonstrating the constitution of the sample of the study. Rio de Janeiro, 2013.

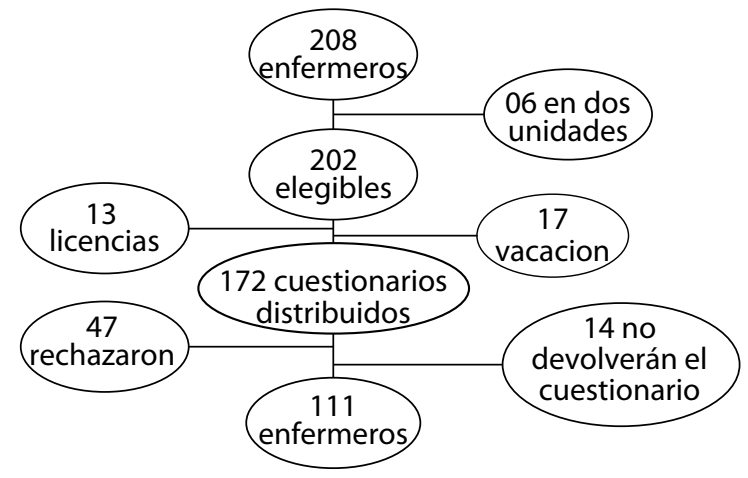

Source: Developed by the authors, 2013.

This study was approved by the Committee of Ethics and Research of the Anna Nery Nursing School/UFRJ (protocol \#108.479); by the Rio de Janeiro Municipal Department of Health and Civil Defense (SMSDC-RJ, in Portuguese; protocol \#129/12); by the Federal Hospital of Bonsucesso (protocol \#126.329); and by the Pedro Ernesto College Hospital/UERJ (protocol \#161.234). It was also accepted by the military units related to the protocols mentioned.

Data collection occurred between November 2012 and February 2013. A self-completion questionnaire consisting of 18 questions regarding the socio-demographic profile and developmental care qualifications related to the newborn on the part of the participant was used.

The data acquired were entered onto EpiData software and sent to a consistency analysis method, which consists in a double typing process. Later, they were transferred to an electronic spreadsheet in Microsoft Excel, version 2007, and then analyzed using R software (version 2013).

The data analyzed were presented in the form of descriptive statistics, percentage values $(\%)$, average $(\overline{\boldsymbol{x}}) \overline{\boldsymbol{x}})$ and confidence intervals $(\mathrm{Cl}$ 95\%), and revealed in tables.

The limitations found in this study were that 14 questionnaires were not returned and 47 nurses declared that they did not wish to participate in this research.

\section{RESULTS}

In terms of the socio-demographical characteristics of the nurses who work in neonatal care units, they were predominantly female (91\%). The ages varied from 25 to 57 years, with the majority between 30 to 39 years of age $(44.1 \%)$, with an average of 38 years of age [IC 95\%, 36.61-39.49].

Regarding the time since graduation, $45 \%$ of the nurses graduated between 1 to 9 years ago, with an average of 12.54 years [IC 95\%, 11.09-13.99]. The majority of these are specialists $(42.3 \%)$ with less than 10 years of professional experience. The average is 12.5 years [IC 95\%, 11.10-14.05], with 9.51 years [IC 95\% 8.06-10.96] of experience in neonatal care. See Table 2.

Table 2 - Sociodemographic profile of neonatal nurses. Rio de Janeiro, 2013.

\begin{tabular}{|c|c|c|c|c|}
\hline Variables & $n=111$ & $\%$ & & $\mathrm{Cl} 95 \%$ \\
\hline \multicolumn{5}{|l|}{ Gender } \\
\hline Male & 10 & 9 & & $3.68-14.32$ \\
\hline Female & 101 & 91 & & $85.68-96.32$ \\
\hline Age & & & 38 & $36.61-39.49$ \\
\hline 20-29 years old & 16 & 14,4 & & $7.87-20.93$ \\
\hline 30-39 years old & 49 & 44,1 & & $34.86-53.34$ \\
\hline $40-49$ years old & 33 & 29,7 & & $21.20-38.20$ \\
\hline 50-59 years old & 13 & 11,7 & & $5.72-17.68$ \\
\hline \multicolumn{2}{|l|}{ Years of Training } & & 12,54 & 11.09-13.99 \\
\hline 01-09 years & 50 & 45 & & $35.74-54.26$ \\
\hline $10-19$ years & 39 & 35,1 & & $26.22-43.98$ \\
\hline 20-29 years & 21 & 18,9 & & $11.62-26.18$ \\
\hline 30-39 years & 1 & 0,9 & & $0.00-2.66$ \\
\hline \multicolumn{3}{|c|}{$\begin{array}{l}\text { Years of Professional } \\
\text { Experience }\end{array}$} & 12,5 & $11.10-14.05$ \\
\hline $\begin{array}{l}\text { Less than one } \\
\text { year }\end{array}$ & 3 & 2,7 & & $0.00-5.72$ \\
\hline 01-09 Years & 44 & 39,6 & & $30.50-48.70$ \\
\hline 10-19 Years & 41 & 36,9 & & $27.92-45.88$ \\
\hline 20-29 Years & 22 & 19,8 & & $12.39-27.21$ \\
\hline 30-39 Years & 1 & 0,9 & & $0.00-2.66$ \\
\hline \multicolumn{3}{|c|}{$\begin{array}{l}\text { Years of experience in neo- } \\
\text { natal }\end{array}$} & 9,51 & $8.06-1.96$ \\
\hline $\begin{array}{l}\text { Less than one } \\
\text { year }\end{array}$ & 18 & 16,2 & & $9.35-23.05$ \\
\hline 01-09 Years & 42 & 37,8 & & $28.78-46.82$ \\
\hline
\end{tabular}




\begin{tabular}{|c|c|c|c|c|}
\hline $10-19$ & 27 & & & \\
\hline 20-29 Years & 14 & 126 & & $6.43-18.77$ \\
\hline \multicolumn{3}{|c|}{$\begin{array}{l}\text { Years of experience working } \\
\text { in neonatal }\end{array}$} & 5,98 & $4.80-7.17$ \\
\hline $\begin{array}{l}\text { Less than one } \\
\text { year }\end{array}$ & 32 & 28,8 & & $20.38-37.22$ \\
\hline 01-09 Years & 48 & 43,2 & & $33.98-52.42$ \\
\hline 10-19 Years & 27 & 24,3 & & $16.32-32.28$ \\
\hline 20-29 Years & 4 & 3,6 & & $0.13-7.07$ \\
\hline \multicolumn{5}{|c|}{ Professional Education } \\
\hline Specialist & 82 & 73,8 & & $65.73-82.07$ \\
\hline Non-specialist & 29 & 26,1 & & $17.93-34.27$ \\
\hline
\end{tabular}

Source: Generated by the authors, 2013.

In most of the cases (72\%), the respondents had worked for less than 10 years in their present health unit, with an average of 5.98 years [IC $95 \%$ 4.80-7.17]. $73.8 \%$ of the nurses are specialized, with $54.9 \%$ of them in neonatal care.

With regard to the work bond, the majority are employed by the state $(76.5 \%)$ working on day shifts (64.8\%). $48.6 \%$ of the respondents work 12 hour shifts with 60 hours of rest periods between shifts.

In terms of employment history, the majority of the nurses $(86.4 \%)$ have worked in more than one place, $82.2 \%$ work have worked in other caring jobs, and most of them (72.9) have worked in different areas from neonatal care. However, $72 \%$ report fulfillment and satisfaction in terms of their working conditions (Table 3 ).

Table 3 - Sociodemographic profile of neonatal nurses. Professional performance. Rio de Janeiro, 2013.

\begin{tabular}{lccc}
\hline \multicolumn{1}{c}{ Variables } & $\mathbf{n = 1 1 1}$ & $\%$ & $\mathrm{Cl} 95 \%$ \\
\hline Functional bond & & & \\
\hline Public worker & 85 & 76,5 & $68.61-84.39$ \\
In a cooperative/hired & 17 & 15,3 & $8.60-22.00$ \\
Others & 9 & 8,1 & $3.02-13.18$ \\
\hline Work regime & & & \\
\hline Daily (rotine) & 18 & 16,2 & $9.35-23.05$ \\
Shift 12/60 day & 54 & 48,6 & $39.30-57.90$ \\
Shift 12/60 night & 26 & 23,4 & $15.52-31.28$ \\
Others* & 13 & 11,7 & $5.72-17.68$ \\
\hline
\end{tabular}

\begin{tabular}{|c|c|c|c|}
\hline \multicolumn{4}{|c|}{ Other functional bonds } \\
\hline None & 15 & 13,5 & 7.14-19.86 \\
\hline One more & 86 & 77,4 & $69.62-85.18$ \\
\hline Two more & 9 & 8,1 & $3.02-13.18$ \\
\hline Three more & 1 & 0,9 & $0.00-2.66$ \\
\hline \multicolumn{4}{|c|}{ Tasks developed in other working areas } \\
\hline Assistence & 79 & 82,2 & $75.08-89.32$ \\
\hline Teaching & 8 & 8,3 & $3.17-13.43$ \\
\hline Administrative role & 8 & 8,3 & $3.17-13.43$ \\
\hline \multicolumn{4}{|l|}{ Performed in: } \\
\hline Neonatal area & 39 & 35,1 & $31.46-49.74$ \\
\hline Other areas & 72 & 64,9 & 64.63-81.17 \\
\hline \multicolumn{4}{|c|}{ Satisfaction regarding working conditions } \\
\hline Yes & 80 & 72 & $63.65-80.35$ \\
\hline No & 31 & 27,9 & $19.56-36.24$ \\
\hline
\end{tabular}

Source: Generated by the author, 2013.

*Others (Shifts of $24 \times 72$ and $24 \times 120$ ); $\mathrm{Cl}=$ confidence interval.

When analyzing the professional education of the nurses regarding developmental care, $78.3 \%$ affirm that they had taken part in information/workshops throughout their professional career, while the majority (37.9\%) a large proportion learned about developmental care during undergraduate and specialization courses.

With regard to the source of this information, the majority of the nurses (72\%) acquired it through books, followed by learning in service (63\%), and through an awareness of institutional protocols (46.8\%). A total of $63 \%$ of the nurses affirmed that they had not participated in courses and/or workshops regarding topics related to developmental care, despite the fact that $74.7 \%$ of them have participated in courses and/ or workshops about other topics, including the Kangaroo Method.

With regard to the existence or otherwise of directives/protocols/routines regarding the topics that are associated with developmental care in their units, $35.1 \%$ of the nurses responded that they exist, while $20.7 \%$ declared that they do not exist in their workplaces. Meanwhile, $44.1 \%$ were unable to answer, as shown in Table 4. 
Table 4 - Professional education of neonatal nurses in the area of developmental care. Rio de Janeiro, 2013.

\begin{tabular}{|c|c|c|c|}
\hline Variables & $n=111$ & $\%$ & $\mathrm{Cl} 95 \%$ \\
\hline \multicolumn{4}{|c|}{ Information about the professional education } \\
\hline Yes & 87 & 78,3 & $70.63-85.97$ \\
\hline Undergraduation & 22 & 25,2 & $17.12-33.28$ \\
\hline Specialization & 32 & 36,7 & 27.73-45.67 \\
\hline $\begin{array}{l}\text { Undergraduation } \\
\text { and Specialization }\end{array}$ & 33 & 37,9 & 28.87-46.93 \\
\hline No & 24 & 21,6 & 13.94-29.26 \\
\hline \multicolumn{4}{|c|}{ Sources of information about the topic } \\
\hline Books & 80 & 72 & $63.65-80.35$ \\
\hline Journals/Magazines & 28 & 25,2 & $17.12-33.28$ \\
\hline $\begin{array}{l}\text { International stan- } \\
\text { dards }\end{array}$ & 1 & 0,9 & $0.00-2.66$ \\
\hline $\begin{array}{l}\text { Ministry of Health } \\
\text { Manuals }\end{array}$ & 45 & 40,5 & $31.37-49.63$ \\
\hline Internet & 41 & 36,9 & $27.92-45.88$ \\
\hline Scientific events & 46 & 41,4 & $32.24-50.56$ \\
\hline $\begin{array}{l}\text { Workshops during } \\
\text { scientific events }\end{array}$ & 37 & 33,3 & 24.53-42.07 \\
\hline $\begin{array}{l}\text { Workshops given by } \\
\text { the Ministry of Health } \\
\text { Workshops given by }\end{array}$ & 19 & 17,1 & $10.10-24.10$ \\
\hline $\begin{array}{l}\text { class associations/pro- } \\
\text { fessional unions }\end{array}$ & 24 & 21,6 & 13.94-29.26 \\
\hline $\begin{array}{l}\text { Orientation given by } \\
\text { supervisors }\end{array}$ & 51 & 45,9 & $36.63-55.17$ \\
\hline $\begin{array}{l}\text { Learning from } \\
\text { practice }\end{array}$ & 70 & 63 & $54.02-71.98$ \\
\hline Institutional protocol & 52 & 46,8 & $37.52-56.08$ \\
\hline Others & 2 & 1,8 & $0.00-4.27$ \\
\hline $\begin{array}{c}\text { Does not use any } \\
\text { sources of information }\end{array}$ & 4 & 3,6 & $0.00-7.07$ \\
\hline
\end{tabular}

\begin{tabular}{|c|c|c|c|}
\hline \multicolumn{4}{|c|}{$\begin{array}{l}\text { Participation in workshops/training about the } \\
\text { topic }\end{array}$} \\
\hline Yes & 41 & 36,9 & $27.92-45.88$ \\
\hline No & 70 & 63 & $54.02-71.98$ \\
\hline
\end{tabular}

Participation in

workshops/training

about other topics

\begin{tabular}{llll} 
Yes & 83 & 74,7 & $66.61-82.79$ \\
No & 28 & 25,2 & $17.12-33.28$ \\
\hline
\end{tabular}

Existence of directives/protocols/routines about the topic in the health unit

\begin{tabular}{llll} 
Does not know & 49 & 44,1 & $34.86-53.34$ \\
Yes & 39 & 35,1 & $26.22-43.98$ \\
No & 23 & 20,7 & $13.16-28.24$ \\
\hline
\end{tabular}

Source: Generated by the authors, 2013.

\section{DISCUSSION}

The majority of the nurses (91\%) are women, which suggests that nursing is yet a predominantly female profession, with an average of 38 years of age. Similar information regarding the socio-demographic characteristics in terms of gender and age was found by another study ${ }^{(6)}$ performed in the city of Rio de Janeiro.

Based on the age group, it can be seen that there is a degree of aging with regard to the workforce involved in neonatal care nursing - especially when compared to the previous research $^{(7)}$ in the same municipality. This aging is worrying when other studies ${ }^{(8 ; 9 ; 10)}$ demonstrate that the declining age of nurses and physicians in neonatal care is a triggering factor in terms of occupational stress.

Nation-wide analysis ${ }^{(6 ; 8 ; 10)}$ highlights that another aspect to be considered as a stimulus for this type of stress is the amount of working places. In this study, the large majority of the nurses (86.4\%) work in more than one place, with $82.2 \%$ of them working in another caring job. In addition, other international studies ${ }^{(11 ; 12)}$ report an increase in the age of nurses, a reduction in the number of young students in undergraduate nursing programs, and the possible non-replacement of professionals of retirement age, thus leading to a decrease in the number of nurses working in the area. Such factors, in addition to harming the health of the care worker, can also compromise the quality of the care service provided ${ }^{(6)}$ to the NB.

Anther aspect related to the quality of neonatal care is related to the period of professional experience in the area, which, in this study, was found to be less than 10 years (45\%). A similar result was found in a previous analysis ${ }^{(7)}$, in which the authors highlight that the largest work experience period permitted the nurse to have "a consolidated practical experience" and time to 
educate themselves, which are necessary conditions for developing a higher quality care service.

It is important to mention that the majority $(73.8 \%)$ of the nurses who work in neonatal care are specialized, being $54.9 \%$ of them specialized in neonatal care, while the others are specialists in other areas or care. Specialization programs aim to ensure technical-professional improvement, qualified training, adaptation to the labor market, and the introduction to scientific research. Despite the importance of giving more technical information to nurses, the specialization program related to the search for educational improvement comes from the individual herself, or in other words, as a result of personal professional motivation. Many health institutions do not have career plans, and do not have wage differentiation for nurses with specialization degrees ${ }^{(7)}$.

International directives ${ }^{(13)}$ emphasize that for intensive neonatal care, the nurse must have specialized technical-scientific knowledge, a leadership role, the capacity to work in and stimulate a team, high levels of organizational ability, self-observation, discernment, and critical ability .

In Brazil, there is a lack of studies about the profile of nurses who work in neonatal intensive care units. Due to the complexity of the care provided to NB in a critical condition, in service training is a necessity. It is fundamental when the nurse does not have any formal understanding in the area of neonatal care, a situation seen as common to those nurses who work in the area of health as public service workers - with this study finding that this is the case with $76.5 \%$ of the professionals studied. Despite this, health services that require nurses to work in NICU employ professionals with a generalized educational background. This can influence the quality of healthcare provided to the $\mathrm{NB}^{(7)}$.

Other studies ${ }^{(8 ; 9)}$ show that there are many factors that interfere in the quality of healthcare provided to the NB and his family: the devaluation of the professional, the stress affecting professionals when dealing with death situations, patients' overcrowding, the need to update the professional's knowledge in the area, personal relationships among health professionals, relationships between professionals and parents and NB, low wages, lack of technical resources, demands of administrative roles that move the nurse away from the direct care of the NB, and the need to deal with the emotional overload of the family with regard to the premature child.

The quality of nursing care provided is also related to the nurse/patient ratio. Resolution \#930/2012 describes the minimal conditions for the functioning of NICU inside the Brazilian Unified Health System (SUS, in Portuguese). It is mandatory to have, at least, one nurse per shift for every ten NICU beds, and one nursing technician for every two patients ${ }^{(1)}$. Despite the fact that these are basic requisites, many health institutions size their professional body in a more restrictive way than the law requires, keeping a reduced number of nurses in particular caring situations that naturally demand a greater number of professionals ${ }^{(14)}$.

A particular study ${ }^{(14)}$ that aimed to ascertain the size of the nursing staff inside a neonatal care unit in a college hospital located in São Paulo, Brazil, found an overload of tasks and roles as a result of an insufficient number of staff and an elevated demand for care. The authors highlight that work overload is also a risk factor with regard to iatrogenic occurrences, compromising the safety of the NB and the quality of care.

Despite the countless challenges that are present in terms of the health practices of the nurses sampled, this research found that $72 \%$ of professionals are satisfied with their working conditions, giving as reasons the constant update of information related to the area through 
continuous education, the flexibility of working hours allowing staff to improve professionally, the existence of interaction between the members of the multiprofessional team, and working with technically qualified professionals. Similar information was found in an international study, aimed at analyzing the relationship between the workplace, stress, and the quality of neonatal healthcare provided. The results showed that more than $80 \%$ of professionals involved were satisfied with their working conditions and the healthcare service provided ${ }^{(15)}$.

A less positive result was found in another study $^{(6)}$ performed in the city of Rio de Janeiro, Brazil, in large public hospitals, with $53.7 \%$ of nurses satisfied with their working conditions. Despite the fact that they were in the majority, the authors showed that there was a certain lack of interest in their profession when they found, in some of the results, that $36.1 \%$ had thought of abandoning the profession more than once, and that $14.3 \%$ thought of doing the same, but more frequently.

With regard to the professional qualifications of the nurses in developmental care, this present study shows that the majority $(78.3 \%)$ received some information throughout their professional life, in undergraduate and/or specialization programs. However, the main source of information does not specifically mention this philosophy of care. As previously discussed, the generalist nature of undergraduate programs contributes to an apparent lack of ability and preparedness on the part of nurses in NB care in $\mathrm{NICU}^{(2)}$. Despite this, the education of nurses needs to innovate the process of learning, using more multimedia resources that stimulate the student/future professional and help him to understand the complexity of this type of care. There is also a need to promote the transition of the information discussed and of clinical practice ${ }^{(12)}$, by developing understanding, mainly through the use of evidence found in the scientific literature.

Despite the fact that the Brazilian Southeast region has the highest number of specialization programs ${ }^{(5)}$, there are no courses designed exclusively for neonatal intensive care, with an emphasis in developmental care. Furthermore, the great technological improvements in the area of health, especially in neonatal care, have brought about an increased amount of information with the potential to contribute to transformations in nursing care practice, but at the same time demanding a dynamic movement of on the part of these professionals in order to keep up to speed. To follow up and complement their understanding, the neonatal nurse must engage in continuous improvement, and needs to have access to scientific literature ${ }^{(5)}$.

In development care today, a vital element of the NICU must be individualized care, supported by caring centered on the family and in the favorable environment essential to the development of the NB. The model of developmental care is based on an understanding of the maturation of the brain of the fetus, essential to providing the professional with a comprehension of the language of the NB, thus permitting them to observe any signs of stress ${ }^{(4)}$. Besides that, it must also promote the training of parents/relatives in terms of perceiving such signs. Health professionals need competence and the ability to understand this language, and to promote actions that permit the growth and the development of the NB at the NICU.

The specialized care provided by nurses in intensive care has an influence over the clinical evolution of the patient. The individual care in health management, the monitoring and the evaluation of the responses, improve the clinical results, reducing complications, morbidity and mortality, and also presenting good results in reducing hospitalization time ${ }^{(16)}$. 
The presence of gaps in this understanding can expose the NB to unnecessary risks related to iatrogenic damage, involving the health system in avoidable expenses, generating significant costs $^{(17)}$. Therefore, there is a need to focus on the viability of access to the information regarding developmental care, as part of the training and evaluation of the practices of health professionals.

The Rio de Janeiro Municipal Health Department (SMS, in Portuguese) is one of the Collaborative Centers of the Brazilian Ministry of Health, responsible for educating professionals that support high-risk NB, according to the directives of the Kangaroo Method, proposed by the Brazilian National Humanization Policy.

The philosophy of developmental care is part of the Kangaroo Method ${ }^{(18)}$ and includes technical care roles to be performed with regard to the NB (handling, attention to individual needs, attention to light, sound and pain); support to the family; the promotion of the mother/ baby bond and breastfeeding; and ambulatory care after discharge, as a strategy to improve neonatal care ${ }^{(4)}$.

Despite the fact that $63 \%$ of the nurses in this study denied that they had participated in workshops and/or training programs regarding topics related to developmental care, the majority declared that they had attended workshops and/or training programs that included topics such as breastfeeding, humanization, newborn pain and the Kangaroo Method. This data show there is a certain distance between understanding and practice, demonstrating that developmental care was not understood completely or fully incorporated in assisting care.

This gap can be related to the resistance of health professionals to innovations and to the replacement of hard technologies, traditionally used in NICU, by softer technologies based on human interaction ${ }^{(18)}$. Or it can also be associated with the transition of the focus of care associated with biological aspects to an association of these elements to the affective, psychological, and social aspects, necessary to the administration of care that promotes not only the survival of the babies, but also to their neurological development and their integration into family life ${ }^{(2)}$.

Another challenge with regard to disseminating the understanding and the incorporation of this fact to practice, is the challenge of gathering professionals together during or after working hours, and the lack of infrastructure. Despite this, the strategies to amplify the dissemination of understanding depend on the workers themselves, and on the healthcare service provided without having formal financial institutional support - which reduces the consistency of their use ${ }^{(19)}$.

Therefore, the lack of awareness of directives/protocols/routines in developmental care by the surveyed nurses may be related to a real lack of these instruments, or to a distant attitude on the part of senior nurses regarding such proceedings, because the role of a boss/ leader is fundamental to the process of the dissemination of knowledge ${ }^{(19)}$. Such distancing can be related to the multidisciplinary character towards developmental care, which will demand of the nurses, besides the administrative roles and the viability of the caring process of the nursing team, a certain conformity with the other components of the multidisciplinary team, which demands a more proactive stance on the part of these professionals ${ }^{(13)}$.

With regard to developmental care, its dissemination and incorporation when it comes to assisting nursing care are fundamental to the development of the baby, and demands a use of long-term strategies and institutional support to support the method. This is currently a great challenge for the public health services of the city of Rio de Janeiro(18). 


\section{CONCLUSION}

Neonatal nursing needs higher visibility. It is considered nationally and internationally to be a priority area. Despite this, little is known about the conditions present in the work processes of the neonatal nurse, and their relationship with the quality of the service provided to the NB in NICU.

The results of this study demonstrate that the professionals are of a mature age, but with little work experience in the neonatal area, work in different locations, and with the majority possessing a specialist degree. With regard to qualifications and the developmental care of the NB, gaps in the dissemination of this understanding were observed. This is one of the great challenges for the health services and for caring practice.

Therefore, there is an effective need to disseminate the ideas of developmental care through a process of permanent education, from the consolidation of evidence of their effectiveness and the resolution for acute cases in NB, rectifying the need to increase the importance of the participation of the family, and of this model of care for the development of the baby.

\section{REFERENCES}

1. Brasil. Ministério da Saúde. Portaria n. ${ }^{\circ} 930$, de 10 de maio de 2012. Define as diretrizes e objetivos para a organização da atenção integral e humanizada ao recém-nascido grave ou potencialmente grave e os critérios de classificação e habilitação de leitos de Unidade Neonatal no âmbito do Sistema Único de Saúde (SUS). Diário Oficial [da] República Federativa do Brasil. 2012 May 10; Seção 1. [cited 2013 Nov 29] Available from: http://bvsms.saude.gov.br/bvs/saudelegis/ gm./2012/prt0930_10_05_2012.html

2. Costa R, Padilha MI. A Unidade de Terapia Intensiva Neonatal possibilitando novas práticas no cuidado ao recém-nascido. Rev. Gaú- cha Enferm. (Online) [serial on the Internet]. 2011 June [cited 2014 Jan 05] ; 32( 2 ): 248-255. Available from: http://www.scielo. $\mathrm{br} / \mathrm{scielo}$.php?script=sci_arttext\&pid=S1983-14472011000200006\&lng=en. DOI: http:// dx.doi.org/10.1590/S1983-14472011000200006.

3. McAnulty G, Duffy FH, Kosta S, Weisenfeld NI, Warfield SK, Butler SC, et al. School-age effects of the newborn individualized developmental care and assessment program for preterm infants with intrauterine growth restriction: preliminary findings. BMC Pediatrics 2013 [cited 2013 Dec 26];13:25. Available from: http://www. biomedcentral.com/1471-2431/13/25

4. Brasil. Ministério da Saúde (Brasil). Secretaria de Atenção a Saude. Departamento de Ações Programáticas Estratégicas. Atenção humanizada ao recém-nascido de baixo peso: Método Canguru. 2. ed. Brasília: Ministério da Saúde; 2011.

5. Costa R, Padilha MI, Monticelli M. Produção de conhecimento sobre o cuidado ao recém-nascido em UTI Neonatal: contribuição da enfermagem brasileira. Rev. Esc. Enferm. USP [internet]. 2010 [cited 2013 Dec 15];44(1):199-204. Available from: http://www.scielo.br/pdf/reeusp/v44n1/ a28v44n1.pdf

6. Griep RH, Fonseca MJM, Melo ECP, Portela LF, Rotenberg L. Enfermeiros dos grandes hospitais públicos no Rio de Janeiro: características sociodemográficas e relacionadas ao trabalho. Rev. bras. enferm. [serial on the Internet]. 2013 Sep [cited 2014 Jan 05]; 66( spe ):151-157. Available from: http://www.scielo. $\mathrm{br} / \mathrm{scielo}$.php? script=sci_arttext\&pid=S0034-71672013000700019\&Ing=en

7. Diniz EA. Perfil dos enfermeiros que atuam em unidades de terapia intensiva neonatal e pediátrica no Estado do Rio de Janeiro [dissertation]. Rio de Janeiro: Escola de Medicina da Universidade Federal do Rio de Janeiro/UFRJ; 2008.

8. Versa GLGS, Murassaki ACY, Cristina IK, Melo WA, Wilke FJ, Misue ML. Estresse ocupacional: avaliação de enfermeiros intensivistas que atuam no período noturno. Rev. Gaúcha Enferm [Internet]. 2012 Jun [access 2013 May 01];33(2):78-85. Available from: http://www.scielo.br/scielo.php?script=sci_arttext\&pid=S1983$-14472012000200012 \&$ Ing=en 
9. Fogaça MC, Carvalho WB, Nogueira-Martins LA. Estudo preliminar sobre a qualidade de vida de médicos e enfermeiros intensivistas pediátricos e neonatais. Rev Esc Enferm USP [Internet]. 2010 [access 2013 Dec 15];44(3):708-12. Available from: http://www.ee.usp.br/reeusp/

10. Afecto MCP, Teixeira MB. Avaliação do estresse ocupacional e síndrome de burnout em enfermeiros da unidade de terapia intensiva: um estudo qualitativo. Enfermagem j braz on-line [Internet]. 2009 February [access 2013 Dec 09]; 8 (1):. Available from: http://www.objnursing.uff. br/index.php/nursing/article/view/2107

11. Alexis $O$, Shillingford A. Exploring the perceptions and work experiences of internationally recruited neonatal nurses: a qualitative study. Journal of Clinical Nursing. 2012 [access 2013 Nov 22];21:1435-1442. Available from: http:// onlinelibrary.wiley.com/doi/10.1111/j.13652702.2011.03922.x/abstract

12. LeFlore J, Thomas PE, Zielke MA, Buus-Frank ME, McFadden BE, Sansoucie DA. Educating neonatal nurse practitioners in the 21 st century. The Journal of Perinatal e Neonatal Nursing. 2011 [access 2013 Nov 25];25(2):200-205. Available from: http://www.ncbi.nlm.nih.gov/ pubmed/21540700

13. American Association of Critical Care Nurses (AACN). Standards for Establishing and Sustaining Healthy Work Environments. Access 2013 Nov. Available from: htpp: \lwww.aacn.org.

14. Nunes BK, Toma E. Dimensionamento de pessoal de enfermagem de uma unidade neonatal: utilização do Nursing Activities Score. Rev. Latino-Am. Enfermagem [Internet]. 2013 Jan/Feb [access 2013 Dec 27];21(1):[08 screens]. Available from: www.eerp.usp.br/rlae

15. Rochefort CM, Clarke SP. Nurses' work environments, care rationing, job outcomes, and quality of care on neonatal units. Journal of Advanced Nursing. 2010 [access 2013 Nov 22];66:22132224. Available from: http://onlinelibrary.wiley. com/doi/10.1111/j.1365-2648.2010.05376.x/ abstract

16. Fry, M. (2011), Literature review of the impact of nurse practitioners in critical care services. Nursing in Critical Care, 16: 58-66. doi: 10.1111/j.1478-5153.2010.00437.x
17. Grimshaw JM, Eccles MP, Lavis JN, Hill SJ, Squires JE. Knowledge translation of research findings Implementation Science. 2012 [cited 2013 Dec 15];7:50 Page 2 of 17. Available from: http://www. implementationscience.com/content/7/1/50

18. Gontijo TL, Xavier CC, Freitas MIF. Avaliação da implantação do Método Canguru por gestores, profissionais e mães de recém-nascidos. Cad. Saúde Pública [internet]. 2012 May [cited 2013 Dec 15];28(5):935-944. Available from: http:// www.scielo.br/pdf/csp/v28n5/12.pdf

19. Gomes MASM, Wuillanume SM, Magluta C.Conhecimento e prática em UTI Neonatais brasileiras: a perspectiva de seus gestores sobre a implementação de diretrizes clínicas. Physis Revista de Saúde Coletiva [Internet]. 2012 [cited 2013 Dec 15];22[ 2 ]:527-543. Available from: http://www.scielo. br/scielo.php?script=sci_arttext \&pid=S0103$-73312012000200007 \&$ lng $=$ en

All authors participated in the phases of this publication in one or more of the following steps, in According to the recommendations of the International Committee of Medical Journal Editors (ICMJE, 2013): (a) substantial involvement in the planning or preparation of the manuscript or in the collection, analysis or interpretation of data; (b) preparation of the manuscript or conducting critical revision of intellectual content; (c) approval of the versión submitted of this manuscript. All authors declare for the appropriate purposes that the responsibilities related to all aspects of the manuscript submitted to OBJN are yours. They ensure that issues related to the accuracy or integrity of any part of the article were properly investigated and resolved. Therefore, they exempt the OBJN of any participation whatsoever in any imbroglios concerning the content under consideration. All authors declare that they have no conflict of interest of financial or personal nature concerning this manuscript which may influence the writing and/or interpretation of the findings. This statement has been digitally signed by all authors as recommended by the ICMJE, whose model is available in http://www.objnursing.uff.br/ normas/DUDE_eng_13-06-2013.pdf

Received: 04/19/2014
Revised: 08/19/2014
Approved: 08/19/2014 